\title{
REMARKS ON CHINA'S RATIFICATION OF THE 1982 UN CONVENTION ON THE LAW OF THE SEA
}

\author{
Yu Hui*
}

\section{INTRODUCTION}

Eighteen months after the entry into force of the 1982 United Nations Convention on the Law of the Sea, ${ }^{1}$ China ratified that Convention on 15 May $1996 .{ }^{2}$ On 7 June 1996, it deposited the instrument of ratification with the Secretary-General of the United Nations. ${ }^{3}$ Upon ratification, China made a declaration consisting of four statements, ${ }^{4}$ and on the same day it announced the long due baselines for measurement of the territorial sea. ${ }^{5}$

While China had participated actively in the Third United Nations Conference on the Law of the Sea (UNCLOS III) and had signed the Convention on the day it was opened for signature, on 10 December 1982, a variety of factors delayed its ratification. Among them were the difficulty of reconciling China's position on innocent passage by warships through the territorial sea with the Convention's provisions, overlapping maritime claims with opposite and adjacent neighbouring States, territorial disputes over some

\footnotetext{
* Ph.D. Candidate, University of Amsterdam; LL.M., Dalhousie Law School; LL.M., Peking University; Corresponding research fellow, Institute of International Law, Peking University; former Legal Officer, State Oceanic Administration of China. When this comment was written, the author was a guest research fellow at the Max Planck Institute for Comparative Public Law and International Law, to which the author owes gratitude for both intellectual and financial support. The author would also like to thank Dr. Peter Macalister-Smith for his helpful contribution during the preparation of these Remarks.

${ }^{1}$ The Convention entered into force on November 16, 1994.

${ }^{2}$ In accordance with the decision of the 19th meeting of the Standing Committee of the 8th National People's Congress.

${ }^{3}$ The Convention entered into force for China on the 30th day following the deposit of the instrument of ratification, and China became the 93rd State party to the Convention.

${ }^{4}$ See People's Daily (overseas ed.), May 16, 1996, p. 4. The English text in this article is the author's translation.

${ }^{5}$ The geographical coordinates of some territorial sea baselines of the continent, and the territorial sea baselines of the Xisha Islands. For the English text, see China Daily, May 16, 1996.
}

Asian Yearbook of International Law, Volume 5 (Ko Swan Sik et al., eds.; 90-411-0375-9

(c) 1997 Kluwer Law International; printed in the Netherlands), pp. 211-230 
groups of islands, and uncertainty as to the financial obligations arising under the Convention.

The ratification of the Convention with the Declaration accompanying it demonstrates China's willingness to defend its maritime rights and address its maritime problems by reference to international law. It is also of importance for the promotion of peace in East and Southeast Asia where significant conflicts exist between China's maritime claims and those of others.

This note will briefly review the historical development of the law of the sea in China, China's position during the UNCLOS III and the possible reasons for final ratification of the Convention, then comment on the four statements contained in the Declaration made upon ratification of the Convention, and conclude with a review of the underlying policy.

\section{CHINA AND THE LAW OF THE SEA}

\subsection{Historical note}

China has a 18,000 km continental coastline, and another $14,000 \mathrm{~km}$ coastline around some 6,500 islands scattered in the Bohai (an internal sea), the Yellow Sea $\left(400,000 \mathrm{~km}^{2}\right)$, the East China Sea $\left(700,000 \mathrm{~km}^{2}\right)$, and the South China Sea $\left(3,400,000 \mathrm{~km}^{2}\right)$. These are all enclosed or semi-enclosed seas between China and neighbouring States, and the resulting maritime boundary problems remain to be settled.

Although China for centuries led the world in the development of nautical technology, with its ships sailing to the farthest reaches of the Indian Ocean before the time of the Roman Empire, its ancient emperors did not feel the need for expansion of their power overseas. Its nautical activity waned by the 16th century of the present era, and this was followed by the arrival of the European colonial powers. While under the Qing Dynasty, China divided the oceans into "Nei Yang" (inner ocean) and "Wai Yang" (outer ocean), it was in 1864, with the introduction of HENRY WHEATON's Elements of International Law to China, that China formulated a clearer conception of territorial sea jurisdiction. In that year, during the Prussian-Danish War, a Prussian warship captured three Danish merchant ships in the Gulf of Bohai. China's Qing government protested on the ground that the capture was made within the Chinese "inner ocean", basing its position on the principles of international law contained in the Chinese translation of WHEATON's work. Acknowledging 
the illegality of its act, Prussia released two of the Danish ships, and paid compensation for the third. ${ }^{6}$

The first delimitation of China's territorial sea can be traced back to the 1930s. At the Hague Codification Conference in 1930, the Chinese delegation declared itself in favour of limiting the territorial sea to a breadth of 3 nautical miles (nm) from the low water mark along the coast. ${ }^{7}$ In 1931, the State Council of the Republic of China adopted a decree, which provided that the limit of the territorial sea was to be $3 \mathrm{~nm}$, and the limit of an anti-smuggling zone was $12 \mathrm{~nm} .{ }^{8}$ This decree was the first legislative act in Chinese history formally establishing the territorial sea.

When the Taiwan crisis developed in 1958 China (the People's Republic of China), finding it necessary to warn other countries not to send warships to the aid of the Taiwan "Nationalists", made a Declaration on the Territorial Sea, which stated that: (1) the breadth of China's territorial sea was $12 \mathrm{~nm}$; (2) straight baselines would be applied as appropriate for the delimitation of China's territorial sea; (3) no foreign military vessels or aircraft could enter China's territorial sea or the air space above it without permission; and (4) the foregoing principles would apply to Taiwan and its surrounding islands and to all islands belonging to China. ${ }^{9}$ Since then, the 1958 Declaration has served as the basis for China's policy on the law of the sea.

A comprehensive legal regime for the oceans was gradually taking shape at the international level at UNCLOS III, with China beginning to participate in the Conference in 1973. In the early 1980s, a series of basic maritime laws and regulations were enacted, including the 1982 Marine Environmental Protection Law, the 1983 Maritime Traffic Safety Law, the 1986 Fisheries Law, the 1986 Mineral Resources Law, the 1987 Customs Law, the 1992 Maritime Code, and most importantly, the 1992 Law on the Territorial Sea and the Contiguous Zone. ${ }^{10}$

\footnotetext{
${ }^{6}$ See WANG TIEYA, 'International Law in China: Historical and Contemporary Perspectives', 221 RdC (1990-II) 232-233; see also CHIU HungdAH, 'China and the Question of Territorial Sea', 1 International Trade Law Journal (1975) 33.

${ }^{7}$ For conference documents concerning the width of the territorial sea and the position of the Chinese delegation, see 24 AJIL (Supp. 1930), 25, 27, 234-235, and 254.

${ }^{8}$ For the text of the Order, see Collection of Laws and Decrees of the Republic of China (1934), Part IV, 715.

${ }^{9}$ For English text of the Declaration, see Peking Review, No. 28, September 9, 1958, 21.

${ }^{10}$ This list is not exhaustive. For the English text of these laws and regulations, see Office of Laws and Regulations, Department of Ocean Management and Monitoring, State Oceanic Administration (ed.), Collection of the Sea Laws and Regulations of the People's Republic of China (Beijing: China Ocean Press, 1991).
} 
Essentially identical to the 1958 Declaration, the 1992 Law on the Territorial Sea and the Contiguous Zone defines the geographic scope of China's territorial sea as $12 \mathrm{~nm}$ measured from straight baselines, establishes a $12 \mathrm{~nm}$ contiguous zone adjacent to and beyond the territorial sea, prescribes basic rights and duties in these two sea belts, reaffirms China's sovereignty over its coastal islands and all the other islands belonging to China, and provides that ships for non-military purposes have a right of innocent passage whereas foreign warships shall be subject to authorization before entering China's territorial sea. China's 1992 Law on the Territorial Sea and the Contiguous Zone, and its other maritime laws and regulations are intended to establish a comprehensive marine legal system. ${ }^{11}$

\subsection{China and UNCLOS III}

China was not a party to the 1958 Geneva Conventions, which it criticized as serving only the interests of a few big maritime powers. ${ }^{12}$ After its return to the United Nations in 1971, China participated fully throughout the nine years of UNCLOS III. The Working Papers submitted by the Chinese delegation to the Seabed Committee in 1973 clarified China's position on major law of the sea issues. ${ }^{13}$

In general, China viewed UNCLOS III as an arena for the continuing struggle of the Third World, including China, against the hegemony of the superpowers. As to the conduct of the Conference, China supported the adoption of a 'one state, one seat' principle for the distribution of seats in the committees of the Conference. ${ }^{14}$ On substantive issues, China joined the majority of developing countries in demanding extension of coastal State rights up to $200 \mathrm{~nm},{ }^{15}$ and the establishment of an international seabed regime with

\footnotetext{
${ }^{11}$ See Zhao Enbo, 'China's Marine Legal System', in Marine Law and Policy (ed. China Institute for Marine Development Strategy) 1 (1990), 118-125.

${ }^{12}$ See Shen Weiliang, Peking Review, April 15, 1973, 14-15; Qiao Guanhua, Peking Review, October 5, 1973, 15-16; UN Doc. A/AC 138/SC II/SR 57, 1973, 103-105.

${ }^{13}$ See 'Working Paper on Sea Area within the Limits of National Jurisdiction', UN Doc. A/AC 138/SC II/L.34 (July 16, 1973); 'Working Paper on Marine Scientific Research', UN Doc. A/AC 138/SC III/L.42 (July 19, 1973); and 'Working Paper on General Principles for the International Sea Area', UN Doc. A/AC 138/SC II/L.45 (August 8, 1973).

${ }^{14}$ For details, see J. GREenfield, China's Practice in the Law of the Sea (Clarendon Press, 1992), 193-197.

${ }^{15}$ See UN Doc. A/CONF 62/WP 10/Add I (1977).
} 
appropriate machinery based on the concept of "common heritage of mankind". ${ }^{16}$

Convinced that its position on the right of innocent passage was of vital national concern, China reiterated its position that a coastal State has the right to require prior authorization or notification for the passage of foreign military ships through its territorial sea. As to boundary delimitation, China favoured application of the 'natural prolongation' principle for the definition of the continental shelf, and opposed the median line or equidistance criterion, maintaining that delimitation of the exclusive economic zone (EEZ) and the continental shelf between States with opposite or adjacent coasts should be determined through negotiations on an equal footing by the parties concerned, in accordance with the principle of equity. ${ }^{17}$

Though not totally satisfied with the Convention, ${ }^{18}$ China considers it the basic legal document governing international maritime activity that meets the needs of most developing countries for safeguarding their maritime rights and interests. China signed the Convention on 10 December 1982 and ratification of the Convention was considered to be in accordance with China's general interests. Adherence to the Convention also enables China to enjoy broad maritime rights and jurisdiction, such as transit passage through international straits, resource development, environmental protection and scientific research in the EEZ.

The 1994 Agreement relating to the Implementation of Part XI of the United Nations Convention on the Law of the Sea, adjusting and revising the deep seabed mining regime to meet the objections of the industrialized States, also meets China's specific interests in international sea-bed activities. China registered as a pioneer investor in 1991 and enjoys the exclusive rights of exploration for and exploitation of the mineral resources over $150,000 \mathrm{~km}^{2}$ in the northeastern Pacific. Becoming a State party to the Convention ensures the recognition and protection of such rights and interests and allows China to participate in the activities of international institutions like the International Sea-Bed Authority, the International Tribunal for the Law of the Sea, and the Commission on the Limits of the Continental Shelf, thus giving China influence on international marine affairs. ${ }^{19}$

\footnotetext{
${ }^{16}$ See UN Doc. A/AC 138/SC II/L.45 (1973).

${ }^{17}$ See Third UN Conference on the Law of the Sea, Official Records, Vol. XIV, 23-24.

${ }^{18}$ For details, see Shen WeIliang and Xu GuangJian, 'The Third UN Conference on the Law of the Sea and the Convention on the Law of the Sea', Chin. YIL (1983), 433-434.

${ }^{19}$ See the statement by the Chinese vice foreign minister, in People's Daily (overseas ed.), May $13,1996,5$.
} 
However, ratification of the Convention left China with some problems too. In order to clarify its position on some unresolved vital issues and to avoid a potentially disadvantageous impact of the Convention, China made a declaration upon ratification, based on Article 310 of the Convention. The Declaration contains four statements, and is of direct relevance in determining China's actual position on law of the sea issues.

\section{CHINA'S DECLARATION}

\subsection{Statement on the EEZ and Continental Shelf}

During UNCLOS III, China gave its active support to the establishment of a $200 \mathrm{~nm}$ EEZ regime, although China would not be able to extend its jurisdiction up to the permitted limits because the coasts of countries opposite and adjacent to it lay within $400 \mathrm{~nm}$. While China recognized that the 'natural prolongation' principle for the definition of the continental shelf would work in its favour were it to negotiate a division of the continental shelf with Japan, that same principle could work against China when negotiating a maritime boundary with Vietnam. Aware of the complex geomorphology and geology of its maritime areas, committed to its economic reforms, and maintaining a 'soft' border policy and a low-risk foreign policy, China preferred not to embark upon demarcation of its EEZ and continental shelf boundaries. ${ }^{20}$ However, unilateral claims of $200 \mathrm{~nm}$ EEZs, continental shelves and fishery zones made by China's adjacent or opposite coastal States ${ }^{21}$ called for a response from China.

The first statement of the Declaration made upon ratification of the Convention makes specific reference to China's EEZ and the continental shelf for the first time, but does so in a rather ambiguous way. It reads:

\footnotetext{
${ }^{20}$ Some Chinese laws imply jurisdiction over maritime areas wider than the territorial sea. For example, Art. 2 of China's Marine Environmental Protection Law provides that "this law is applicable to the inland waters and territorial seas of the People's Republic of China and all other sea areas under the jurisdiction of the People's Republic of China". "All other sea areas" under Chinese jurisdiction here implicitly refers to the EEZ and the continental shelf of China.

${ }^{21}$ In 1977, Vietnam made a statement on its territorial sea, contiguous zone, continental shelf and exclusive zone; North Korea declared a $200 \mathrm{~nm}$ EEZ; South Korea promulgated a law for the development of submarine mineral resources; Japan proclaimed a $200 \mathrm{~nm}$ fishery zone. In 1978, a Philippine presidential decree proclaimed Kalayaan part of Palawan Province. In 1980, Indonesia and Malaysia proclaimed their rights to $200 \mathrm{~nm}$ EEZ respectively.
} 
"In accordance with the provisions of the United Nations Convention on the Law of the Sea, the People's Republic of China has sovereign rights and jurisdiction over an exclusive economic zone of 200 nautical miles and the continental shelf."

The language used is significant. Geographically China cannot claim an EEZ of up to $200 \mathrm{~nm}$ because of the presence of opposite coastal States within $400 \mathrm{~nm}$. But China explicitly asserts sovereign rights over a $200 \mathrm{~nm}$ EEZ, or an area of $3,000,000 \mathrm{~km}^{2}$, "in accordance with the Convention", thereby insisting on the rights to which it is entitled under the Convention even though it might not be able to exercise them fully. On the other hand, China does not explicitly proclaim the establishment of a $200 \mathrm{~nm}$ EEZ, and the specific limits of China's EEZ and continental shelf are not made clear, thereby avoiding direct confrontation with the adjacent and opposite States which have claimed overlapping rights in the same areas.

Having thus reaffirmed its rights under the Convention, China also acknowledges the responsibilities which it is required to assume under the Convention. This was emphasized by the Director-General of the State Oceanic Administration of China, who referred to the following main obligations in respect of maritime areas, apart from other obligations under the Convention: (1) taking appropriate measures and enacting laws and regulations for the management of maritime activity in those areas; (2) protection and preservation of the marine environment and marine resources; (3) paying due regard to the rights of other States while exercising its own rights; (4) drawing charts for due publicity, and depositing copies of these charts with the Secretary-General of the UN; (5) settlement of maritime disputes through peaceful negotiations. ${ }^{22}$

\subsection{Statement on maritime boundary limitation}

Being one of several States bordering a semi-closed sea raises questions concerning the delimitation of EEZs and the continental shelf. During UNCLOS III, the Chinese delegation repeatedly declared its position in the following terms:

"Delimitation of the exclusive economic zone and the continental shelf between States with opposite or adjacent coasts should be determined through negotiations on an equal footing between the parties concerned, in accordance

22 People's Daily, May 18, 1996, 3. 
with the principle of equity and taking into account all relevant factors and circumstances. This is the only way to attain a result which is fair and just to all parties concerned."23

In the second statement of the Declaration made upon ratification of the Convention China re-affirmed the same principle:

"The People's Republic of China will effect, through consultations, the delimitation of the boundary of maritime jurisdiction with the states with opposite or adjacent coasts on the basis of international law and in accordance with the principle of equity."

The Chinese position is essentially consistent with Articles 74(1) and 83(1) of the Convention, which provide that the delimitation of the EEZ and the continental shelf between States with opposite or adjacent coasts "shall be effected by agreement on the basis of international law, as referred to in Article 38 of the Statute of the International Court of Justice, in order to achieve an equitable solution". What is significant, however, is that China declares that boundary disputes are to be settled through consultations in accordance with the principle of equity, rather than by reference to international tribunals. China views territorial issues as bilateral questions and prefers to resolve them through bilateral and subregional negotiations rather than submit to binding determination by an international arbitration or judicial body. Such a policy is the basis for such statements as: "China is willing to hold bilateral talks with the countries concerned to settle the dispute over the Nansha (Spratly) issue, but opposes the internationalization of the issue." 24 On the other hand, China does not explicitly refuse third party dispute settlement procedures. In accordance with Article 287 and Annex VII of the Convention, China can be deemed to have accepted the principle of recourse to arbitration.

After years of discussing the concept of 'equity' in international law at UNCLOS III, the participating States could find no universally agreed meaning of the term. Accordingly, they settled for the broader reference to delimitation "on the basis of international law", and a specific indication of the objective, viz., "to achieve an equitable solution" in Articles 74 and 83 of the Convention. However, this provision is so general that only by further interpretation

\footnotetext{
${ }^{23}$ See supra $\mathrm{n} .17$.

${ }^{24}$ Statement by the spokesman of the Chinese Foreign Ministry at a press conference; see People's Daily (overseas ed.), July 17, 1992, 1.
} 
can it be made practically applicable. ${ }^{25}$ China's position on the application of the principle of equity is also indeterminate, and subject to different interpretations, and cannot by itself be used as a practical method for boundary delimitation. However, China's clear acceptance of the rule that boundary delimitation questions will be resolved on the "basis of international law" demonstrates its commitment to seeking a peaceful settlement of the issues involved, and is in conformity with Article 279 of the Convention that calls for settlement of disputes by peaceful means in accordance with the Charter of the United Nations.

\subsection{Statement on disputed islands}

The third statement of the Declaration reads:

"The People's Republic of China reaffirms its sovereignty over all archipelagos and islands listed in Article 2 of the Law of the People's Republic of China on the Territorial Sea and the Contiguous Zone promulgated on February 25, 1992."

Article 2 (2) of the 1992 Law on the Territorial Sea and the Contiguous Zone provides that:

"The land territory of the People's Republic of China includes the mainland of the People's Republic of China and its coastal islands; Taiwan and all islands appertaining thereto including the Diaoyu Islands; the Penghu Islands; the Dongsha Islands; the Xisha islands; the Zhongsha Islands; and the Nansha Islands; as well as all the other islands belonging to the People's Republic of China."

This statement has been a source of protests and disputes, because it touches upon difficult territorial issues, including the Diaoyu Islands (Senkaku,

\footnotetext{
${ }^{25}$ Several methods could be adopted to bring about the desired equitable result in ocean boundary delimitation. The following considerations have been identified: (1) geographical considerations: natural prolongation, non-encroachment, distance, proportionality, configuration of coasts, baselines of coastal States, off-shore islands - locations and nature, harbour works, light house and low-tide elevations, equal division of the area of overlap, equal exchange of areas; (2) geological considerations - major constructional variations; (3) geomorphologic considerations; (4) historic interests; (5) environmental-ecological considerations; (6) socio-economic considerations; (7) conduct of State and estoppel; (8) prevention of potential disputes; (9) simplification of the boundary lines. For details, see FU KUEN-CHEN, Equitable Ocean Boundary Delimitation (Taipei: 123 Information Company, 1989).
} 
in Japanese) dispute with Japan in the East China Sea and the multilateral and overlapping claims over the Xisha Islands (Paracel) and Nansha Islands (Spratly) in the South China Sea.

The Diaoyu Islands comprise eight uninhabited islands situated $102 \mathrm{~nm}$ northeast of Taiwan and $240 \mathrm{~nm}$ southwest of Okinawa. Both China (including Taiwan) and Japan claim sovereignty over the Diaoyu Islands, and neither party seems willing to compromise its claims due to the oil resources underlying the sea-bed areas of the islands. Currently the islands are not within the full control of either State, but activities involving these islands frequently raise tension between the two countries. ${ }^{26}$

The South China Sea has two important groups of islands, the Xisha Islands and the Nansha Islands. The Xisha Islands are situated southeast of China's Hainan Island and east of Vietnam. China claims full sovereignty and jurisdiction over the Xisha Islands, over which Vietnam also claims territorial rights. The Nansha Islands comprise a group of hundreds of islands, islets, rocks and reefs, spread over a wide area in an important strategic location which is also rich in fisheries as well as hydrocarbons and other mineral resources. China has from time immemorial claimed sovereignty over all of the Nansha Islands and "their surrounding waters". Attracted by its oil resources, other neighbouring States including Vietnam, Malaysia, Philippines, and Brunei also claim and even occupy some of the islands since the 1970s. From the late 1980s, determined to assert its jurisdiction over the Nansha Islands, China took a series of actions, including promulgating official standard names of the islands in the South China Sea, establishing Hainan Province to strengthen the administrative control over the Xisha and Nansha Islands as well as their surrounding waters, setting up marine scientific survey stations in the area, and taking back some islets of the Nansha Islands, which once resulted in a naval clash with Vietnam in March 1988. ${ }^{27}$

\footnotetext{
${ }^{26}$ For more, see e.g., MA YING-Jeou, Legal Problems of Seabed Boundary Delimitation in the East China Sea, Occasional Papers, 1984; PARK ChOON-Ho \& PARK JAE KYU (eds.), The Law of the Sea: Problems from the East Asian Perspective (Honolulu: The Law of the Sea Institute, University of Hawaii, 1987); PARK CHOON-HO, East Asia and the Law of the Sea (Seoul: Seoul National University Press, 1988); 'Lost at Sea; the Demons of Diaoyu', editorial, FEER, October $17,1996,7$.

${ }^{27}$ For more, see e.g. J.R.V. PresCoTt, The Maritime Political Boundaries of the World (London: Methuen, 1985) Chapter 8: The South China Sea; J.R.V. PresCOTT, Maritime Jurisdiction in Southeast Asia: A Commentary and Map (Honolulu: East-West Center, East-West Environment and Policy Institute, 1981); J.M. VAN DYKE \& D.L. BENNETT, 'Islands and the Delimitation of Ocean Space in the South China Sea', 10 Ocean Yearbook (1993) 54-89; CHEN HURNG-YU, 'A Comparison between Taipei and Peking in their Policies and Concepts regarding the South China Sea', 29 Issues \& Studies (1993) 22-58; L.G. CORDNER, 'The Spratly Islands Dispute and the
} 
The third statement affirms China's sovereignty over the islands and, together with China's 1958 Declaration on the Territorial Sea and the 1992 Law on the Territorial Sea and the Contiguous Zone, will serve as a tool for future negotiations. As PRESCOTT comments: "In the South China Sea, China's insistence that all the Nansha or Spratly Islands and associated submerged banks have belonged to China from time immemorial, will make it very difficult for any country to negotiate with China". ${ }^{28}$ Maritime boundary delimitation there would be exceptionally complicated due to overlapping claims involving six parties without a common basis for negotiation.

Sovereignty disputes over islands cannot be resolved solely by reference to the Convention. According to the latter's unstated premise sovereignty over land territory must be established prior to consideration of maritime issues. The application of relevant articles of the Convention can only be considered after that sovereignty issue is resolved. Furthermore, the extent of the maritime areas that might legitimately be claimed after the issue of sovereignty over the islands is resolved remains unsettled. Article 121 of the Convention provides that an island is entitled to a $12 \mathrm{~nm}$ territorial sea and a $200 \mathrm{~nm}$ EEZ, but "rocks which cannot sustain human habitation or economic life of their own" are excluded from having EEZs or continental shelves. Among the Nansha Islands, only 20 islands protrude above sea level at high tide, and the largest, the Taiping Island (Itu Aba Island), is only $0.43 \mathrm{~km}^{2}$ in area. Almost all of the Nansha Islands are uninhabited and cannot sustain an economic life of their own. It is likely that the maritime delimitation 'effect' with respect to each island will have to be negotiated by reference to all relevant circumstances in order to ensure that the solution achieved is 'equitable'.

While the Convention offers no direct solution for 'island delimitation' issues, its provisions do provide legal guidance towards their peaceful settlement. Thus, Article 279 of the Convention urges States Parties to settle disputes by peaceful means, and Article 197 calls for global and regional cooperation. Articles 74 and 83, reference to which has been made earlier, direct the States concerned to effect delimitation of EEZ's and continental shelfs "by agreement on the basis of international law . . . in order to achieve an equitable solution", and further require that "[p]ending agreement . . . the States concerned, in a spirit of understanding and co-operation, shall make every effort to enter into provisional arrangements of a practical nature . . ." (emphasis added). The latter provision encourages States to adopt a pragmatic

Law of the Sea', 25 ODIL (1994) 61-74; J.I. CHARNEY, 'Central East Asian Maritime Boundaries and the Law of the Sea', 89 AJIL (1995) 724-749.

${ }^{28}$ J.R.V. PRESCOTT, The Maritime Political Boundaries of the World, 92. 
approach designed to reduce and eliminate friction generated by sovereignty issues through "provisional arrangements". Among such arrangements are agreements on "joint development" of concurrently claimed maritime areas that would produce mutual benefits for disputing parties immediately.

'Joint development' refers to joint exploration and exploitation of transboundary or straddling deposits of living or mineral resources under bilateral (or possibly regional) agreements. A device under active consideration by many coastal States since the $1960 \mathrm{~s},{ }^{29}$ it has been endorsed by the ICJ. In the North Sea Continental Shelf Cases, the ICJ held that joint exploitation agreements were "particularly appropriate when it is a question of preserving the unity of a deposit". ${ }^{30}$ Joint development was also envisaged by Judge EVENSEN in his separate opinion in the 1982 Tunisia and Libya Continental Shelf Case.$^{31}$ It was pointed out in the Gulf of Maine Case that the delimitation of a maritime boundary is not necessarily a panacea for disputes over offshore resources, because even successful delimitation may still require a degree of close cooperation if opposite or adjacent States are rationally to exploit transboundary resources. ${ }^{32}$ The case brought to the ICJ by GuineaBissau in 1991 relating to its maritime delimitation with Senegal was discontinued in 1995 due to the conclusion of an agreement on management and cooperation, which contains provisions on joint development of a specific maritime zone. ${ }^{33}$ Joint development arrangements have also been negotiated in Southeast Asia. In 1979, Malaysia and Thailand signed a Memorandum of Understanding on the establishment of a joint authority for the exploitation of hydrocarbons in the Gulf of Thailand. The two countries agreed to implement

\footnotetext{
${ }^{29}$ For more, see e.g. M.J. VAlEnCIA et al., 'Southeast Asian Seas: Joint Development of Hydrocarbons in Overlapping Claim Area?' 16 ODIL (1986) 211-254; E.L. RICHARDSON, 'Jan Mayen in Perspective', 82 AJIL (1988) 443-458; International Law Association's Committee on the Exclusive Economic Zone, Report on Joint Development of Non-Living Resources in the Exclusive Economic Zone, 1988; H. Fox et al., Joint Development of Offshore Oil and Gas (London: British Institute of International and Comparative Law, 1989); W.T. ONORATO \& M.J. VALENCIA, 'International Cooperation for Petroleum Development: the Timor Gap Treaty', 5 ICSID - Foreign Investment Law Journal (1990) 1-29; YU HUI, 'Joint Development of Mineral Resources - An Asian Solution?' 2 AsYIL (1992) 87-112; G.H. BlaKE et al., The Peaceful Management of Transboundary Resources, Graham \& Trotman/Martinus Nijhoff, 1995.

${ }^{30}$ ICJ Rep. (1969) p. 52, para. 99.

${ }^{31}$ ICJ Rep. (1982) p. 18.

32 ICJ Rep. (1984) p. 246.

${ }^{33}$ See S.C. MCCAFFREY, 'Development in Public International Law', 30 International Lawyer (1995) 290.
} 
the arrangement in $1990 .{ }^{34}$ The signing in 1989 of a Treaty on the Zone of Cooperation in the Timor Sea between Indonesia and Australia opened a long disputed area for joint exploitation and highlighted the current interest in such arrangements. ${ }^{35}$ In 1992 Vietnam and Malaysia agreed to explore jointly for hydrocarbons in their overlapping claimed areas in the Gulf of Thailand. ${ }^{36}$

Since the March 1988 clash between China and Vietnam, South China Sea disputes have attracted increasing attention. Proposals for a joint development zone or a 'Spratly Authority' have been put forward. ${ }^{37}$ Indonesia took the initiative in 1990 to launch a quasi-governmental negotiation process, titled "Managing Potential Conflicts in the South China Sea", aimed at getting the claimants and other neighbouring countries to discuss a solution for the disputes. Joint development arrangements were favoured by the States concerned..$^{38}$ The programme has continued to develop avenues for cooperative activities and to foster dialogue among the littoral States of the South China Sea region. ${ }^{39}$

Joint development has also been under active consideration by China, but lack of a clear Chinese proclamation on an EEZ and of delimitation provisions on the Chinese continental shelf, together with doubt about the potential effect of a joint development zone on final boundary delimitation in the South China

\footnotetext{
${ }^{34}$ Memorandum of Understanding between the Kingdom of Thailand and Malaysia on the Establishment of a Joint Authority for the Exploitation of the Resources of the Sea-Bed in a Defined Area of the Continental Shelf of the Two Countries in the Gulf of Thailand, done at Chiang Mai, February 21, 1979, see 6 Energy (1981) 1356-1358; Agreement between the Government of Malaysia and the Government of the Kingdom of Thailand on the Constitution and Other Matters relating to the Establishment of the Malaysia-Thailand Joint Authority, which is designed to implement the Memorandum, May 30, 1990, see D. ONG, 'Thailand/Malaysia: the Joint Development Agreement 1990', Appendix II, 6 International Journal of Estuarine and Coastal Law (1990) 64-72.

${ }^{35}$ Treaty on the Zone of Co-operation in an Area between the Indonesian Province of East Timor and North Australia, December 11, 1989, 29 ILM (1990) 469-537. The Treaty was referred to in the East Timor (Portugal v. Australia) Case, see ICJ Rep. (1995).

36 'Vietnam, Malaysia Agree to Joint Search for Oil', FEER, June 18, 1992, p. 83, as quoted in T.L. MCDorman, 'The South China Sea Islands Dispute in the 1990s - A New Multilateral Process and Continuing Friction', 8 International Journal of Marine and Coastal Law (1993), 274; see also G.H. BLAKE et al., supra n. 29, p. 90.

${ }^{37}$ For example, during the Pacem in Maribus XXI held in Takaoka, Japan, 6-9 September 1993, the South China Sea problem was discussed. See E.M. BORGHESE, 'Pacem in Maribus XXI', 24 Environmental Policy and Law (1994) 21.

${ }^{38}$ See ASEAN Declaration on the South China Sea, Manila, 22 July 1992, in 3 AsYIL (1993) 8. For details, see T.L. MCDORMAN, supra n. 36, pp. 263-285.

${ }^{39}$ For 1994 and 1995 activities, see G.S. HEARNS \& W.G. STORMONT, 'Managing Potential Conflicts in the South China Sea - Report', 20 Marine Policy (1996) 177-181.
} 
Sea, has so far prevented China from taking a final position on proposals for joint development.

\subsection{Statement on innocent passage}

The difficulty of reconciling China's position on innocent passage through the territorial sea with the Convention was one of the main reasons for the delay of China's ratification, and the possible need to amend the relevant Chinese legislation had been the subject of international comment. ${ }^{40}$ The fourth statement of the Declaration does not really resolve the problem. This statement reads:

"The People's Republic of China reaffirms that the provisions of the United Nations Convention on the Law of the Sea relating to innocent passage through the territorial sea do not prejudice the right of the coastal State to require prior authorization or notification in accordance with its laws and regulations for the passage of foreign warships through its territorial sea."

China's position on innocent passage has been consistent. Its 1958 Declaration provides that no foreign military vessels or aircraft may enter China's territorial sea or the airspace above it without permission. During UNCLOS III, under the defense policy aimed at countering the maritime security threat from the two superpowers, China repeatedly proposed inclusion in the Convention of the requirement of prior notification or authorization for foreign worships passing through the territorial sea. ${ }^{41}$ Nevertheless, the Convention's provisions basically serve the interests of the superpowers in

\footnotetext{
${ }^{40}$ See e.g. W.T. BurKe, 'Chinese Perception of the Law of the Sea', in: The Law of the Sea: What Lies Ahead (Honolulu: The Law of the Sea Institute, 1988) 160; KIM HYUN-SoO, 'The 1992 Chinese Territorial Sea Law in the Light of the UN Convention', 43 ICLQ (1994) 896-901.

${ }^{41}$ As early as 16 July 1973 , the Chinese delegation submitted a working paper to the Seabed Committee, in which it suggested that "the foreign non-military ships enjoy the right of innocent passage". "A coastal State may, in accordance with its laws and regulations, require foreign military ships to render prior notification to, or to seek prior approval from, its competent authorities before passing through its territorial sea." UN Doc. A/AC 138/SC II/L.34 (1973). At the 7th session of 1978, since the Informal Composite Negotiating Text had failed to reflect China's suggestion on passage of military ships through the territorial sea, the Chinese delegation pointed out again: "everyone knows that military ships and general commercial ships are two kinds of ships of a different nature. Whether foreign military ships enjoy the right of innocent passage in the territorial sea, is up to the coastal State to decide in accordance with its laws and regulations". See WeI MIN, Law of the Sea [Hai Yang Fa] (Beijing: Law Press, 1987) 80.
} 
protecting naval mobility by including Article $17,{ }^{42}$ to the effect that "ships of all States" enjoy the right of innocent passage. Unwilling to agree, China reiterated its position on the occasion of the adoption of the Convention at the 11th session of the Conference on 30 April $1982,{ }^{43}$ as well as when signing the Convention at the final session on 9 December $1982 .{ }^{44}$ Further reaffirmation of its position took place by the adoption of the 1992 Law on the Territorial Sea and the Contiguous Zone, which finally transformed the policy into a clearly stated legal rule, as follows:

"Foreign ships for non-military purposes shall enjoy the right of innocent passage through the territorial sea of the People's Republic of China in accordance with the law.

Foreign ships for military purposes shall be subject to approval by the Government of the People's Republic of China for entering the territorial sea of the People's Republic of China."

In China's opinion, the view according to which the right of innocent passage extends to ships of all States without distinguishing between warships and merchant ships does not represent general State practice and is not a rule acceptable to all States. ${ }^{45}$

"According to the generally recognized principles of international law, only foreign vessels used for non-military purposes enjoy the right of innocent passage through the territorial sea. The passage of foreign warships through the territorial sea is a matter which bears upon the sovereignty and national security of the coastal State. Naturally, the coastal State has the right to make necessary regulations in respect of such passage." ${ }^{46}$

In other words, since there are no clear provisions regarding the regime of passage of foreign warships through the territorial sea, a coastal State may, according to its laws, require prior notification or approval for the passage of military vessels.

\footnotetext{
${ }^{42}$ Virtually identical with Article 14(1) of the 1958 Convention on the Territorial Sea and the Contiguous Zone, which reads: "Subject to the provisions of these articles, ships of all States, whether coastal or not, shall enjoy the right of innocent passage through the territorial sea". 516 UNTS (1964) 214.

${ }^{43}$ Third UN Conference on the Law of the Sea, Official Records, Vol. XVI, 161-162.

${ }^{44}$ Ibid., Vol. XVII, 102.

${ }^{45}$ Zhou Gengsheng, Guo Ji Fa, [International Law] Vol. 1 (Beijing: Commercial Press, 1959) 23.

${ }^{46}$ See supra n. 17.
} 
Whether foreign military ships enjoy the right of innocent passage in the territorial sea thus remains a controversial issue. Customary international law on the topic is unclear, since State practice and national legislation are not consistent, and the Convention's provisions are ambiguous. Although according to one interpretation "ships of all States" may include warships, when read together with the provisions on the meaning of innocent passage and the rights of protection of the coastal States, the Convention may be understood as implicitly allowing coastal States to enact legislation covering their security interests in the territorial sea. It is also important to note that during the negotiation process the article formed part of a 'package deal' and was adopted without vote. On its adoption, the Conference President made a statement that he "would like to confirm that their decision is without prejudice to the rights of coastal States to adopt measures to safeguard their security interests, in accordance with Article 19 (dealing with the meaning of innocent passage) and Article 25 (dealing with rights of protection of the coastal State) as provided for in the Convention". ${ }^{47}$

At the signing ceremony on 9 December 1982, the Chairman of the Chinese delegation made a statement and clarified the Chinese position:

"At the previous sessions of the Conference, we repeatedly pointed out that in the articles of the Convention relating to the innocent passage through the territorial sea there were no clear provisions regarding the regime of the passage of foreign warships through the territorial sea. A considerable number of States including China time and again submitted their amendment in this regard. To respond to the call of the President of the Conference, the abovementioned co-sponsors of the amendment did not insist on a vote at the session held last April, so that the draft Convention on the Law of the Sea could be adopted by consensus. The statement made by the President of the Conference at that session showed clearly this would not affect the principled position of the co-sponsors demanding that their security be ensured." 48

What is the legal effect of this statement in the context of the Convention? While Article 309 of the Convention expressly prohibits reservations, Article 310 "does not preclude a State, when signing, ratifying, or acceding to this Convention, from making declarations or statements, however phrased or named, with a view, inter alia, to the harmonization of its laws and regulations with the provisions of this Convention, provided that such declarations or statements do not purport to exclude or to modify the legal effect of the

\footnotetext{
${ }^{47}$ Third UN Conference on the Law of the Sea, Official Records, Vol. XVI, 132.

${ }^{48}$ See supra n. 43.
} 
provisions of this Convention in their application to that State". The statement on the innocent passage of warships in territorial waters seems consistent with Article 310. It harmonized China's laws with the Convention, without touching upon the legal effect of Article 17. No true consensus was ever achieved on this Article, which covers an area that is still subject to different interpretations and applications in national practice. ${ }^{49}$

\section{AREAS OF EMPHASIS IN MARITIME POLICY: NATIONAL SECURITY AND JOINT DEVELOPMENT}

China's ratification of the Convention and the accompanying Declaration reflect China's current approach to international law. In the past China generally regarded international law as a tool of western capitalism to subjugate developing countries. With the adoption in the 1980s of a more liberal policy of an open door to the outside world, China's approach to international law changed. It now evaluates existing international rules and customs on the basis of national interests rather than communist ideology, and regards international law as a useful instrument for implementing its policies. $^{50}$

\subsection{National security}

Ratification of the Convention signals that China will treat the Convention as the basis for establishing confidence and good relations with neighbouring coastal States under commonly accepted international legal rules. On the other hand, China believes that its maritime rights and national security must be protected and secured, as evidenced by its insistence on the position that foreign military ships shall be subject to prior authorization for entering

\footnotetext{
${ }^{49}$ In current State practice, there exists a strong preference that the passage of foreign warships shall be subject to prior notification or authorization of the coastal States. E.g. Denmark, Brazil, Sudan, Egypt and India in their national laws require prior permission or notification for passage of foreign warships in their territorial waters. For details, see FRANCIS NGANTCHA, The Right of Innocent Passage and the Evolution of the International Law of the Sea (London: Pinter Publishers, 1990) 147-150.

${ }^{50}$ For more, see e.g. P.C. YUAN, 'China's Challenge to Traditional International Law: An Exposition and Analysis of Chinese Views and Behaviour in International Law and Politics', 10 Dalhousie Law Journal (1987) 9-42; WANG TIEYA, supra n. 6, 199-367; M. BENNETT, 'The People's Republic of China and the Use of International Law in the Spratly Islands Dispute', 28 Stanford Journal of International Law (1992) 425-450.
} 
China's territorial sea. In one view, the latter objective could have been achieved in some other way: by refraining from ratifying the Convention, or by amending the relevant Chinese law. ${ }^{51}$ It should be pointed out that in the general practice of China the provisions of international treaties to which China is a party are applied in the municipal sphere, even if they deviate from national law. ${ }^{52}$ This is clearly spelt out in Article 142 of China's Civil Law $1986,{ }^{53}$ Article 238 of China's Civil Procedure Law 1991, ${ }^{54}$ Article 27 of the Regulations of the People's Republic of China on Consular Privileges and Immunity 1990,55 Article 268 of the Maritime Code of the People's Republic of China 1992, ${ }^{56}$ and Article 14 of the Regulations on Management of Foreign Marine Scientific Research 1996. ${ }^{57}$ However, neither remaining outside the Convention in order to safeguard its position on the issue of innocent passage, nor giving the provision of the Convention on innocent passage precedence over China's law, was an option that appealed to China. China found a way out by simply stating that the Convention's provision on innocent passage does not prejudice China's rights, believing its position could thus be justified.

Over a long history, China has not only made constant and intensive use of the sea, but also has tended to regard the sea as a natural feature that operates to deter foreign invaders. In 1523 , in order to suppress Japanese pirates, the adjacent sea along the Chinese coasts was declared closed. In the 18th century, the Chinese emperor of the Qing Dynasty adopted an isolationist "closed-door and self-defense" policy. The closed door was forced open by the Western gunboats in 1840. During the Sino-Japanese War, the sea and Chinese internal waters were used as the main route by the Japanese for the invasion of China. During the Taiwan Straits crisis in 1958, navy ships of the United States continuously entered China's territorial sea up to $3 \mathrm{~nm}$ from China's coast, which was considered a serious affront to Chinese national dignity. As PRESCOTT observes: "The country which was the victim most frequently was

\footnotetext{
${ }^{51}$ See Wang LiYu and P.H. PeArSe, 'The New Legal Regime for China's Territorial Sea', 25 ODIL (1994) 439.

52 See WANg TIEYA, supra n. 6, p. 333; LI HAOPEI, Tiao Yue Fa Gai Lun [The Law of Treaties] (Beijing: Law Press, 1987) 393; Li ZHAOJIE, 'Effect of Treaties in Domestic Law: Practice of the People's Republic of China', 16 Dalhousie Law Journal (1993) 93.

${ }^{53}$ For the English text of this Law, see The Laws of the People's Republic of China (1983-1986), (Beijing: Foreign Language Press, 1987) 225-249.

${ }^{54}$ For the English text of this Law, see The Laws of the People's Republic of China (1990-1992), (Beijing: Science Press, 1993) 185-240.

${ }_{55}$ For the English text of the Regulations, see ibid. pp. 115-122.

${ }^{56}$ For English text of this Law, see ibid., pp. 411-467.

${ }^{57}$ See People's Daily, June 29, 1996, 3.
} 
China, which had gunboat diplomacy applied against it on twenty-three occasions" ${ }^{58}$ These historical events gave the Chinese people a strong sense of being threatened by foreign navy ships which, therefore, should in no way enjoy innocent passage in China's territorial sea.

\title{
4.2. Joint development
}

A feature of China's flexibility on maritime issues is its willingness to consider joint development of marine resources. This can be seen specifically in its adoption of a policy of "putting aside the question of disputes and instead jointly developing resources in the disputed area". As the Chinese leader DENG XIAOPING once remarked:

\begin{abstract}
"International disputes that have not been handled right can reach the flash point. I asked them (foreign guests) whether the policy of 'one country, two systems' could be adopted in some cases and the policy of 'joint development' in others . . . We Chinese stand for peace and hope to solve disputes by peaceful means. What kind of peaceful means? 'One country, two systems', and 'joint development'."'s9
\end{abstract}

The concept of joint development is not of Chinese origin. In Asia, in 1974 Japan and South Korea concluded an agreement for joint development of a part of the continental shelf of the two countries in the northeast of the East China Sea, ${ }^{60}$ to which China responded sharply. Nevertheless, the idea of joint development of overlapping claims areas is under careful study by China. Following the adoption of a more liberal political policy, and motivated by the prospect of financial gains that could be used for China's modernization, and that of attracting Japanese capital and technology, China proposed to Japan that the disputes over the Diaoyu Islands should be put aside and that consideration should be given to jointly developing oil resources in the area. However, due

\footnotetext{
58 J.R.V. PRESCOTT, The Maritime Political Boundaries of the World, supra n. 27, p. 122.

${ }^{59}$ Speech by DENG XIAOPING at the Third Plenary Session of the Central Advisory Committee of the Communist Party of China in October 1984. See DENG XIAOPING, Jianshe Juyou Zhongguo Tese De Shehuizhuyi [Build Socialism with Chinese Characteristics] (Beijing: Foreign Language Press, 1985) 24.

${ }^{60}$ Agreement between Japan and the Republic of Korea concerning Joint Development of the Southern Part of the Continental Shelf adjacent to the Two Countries, dated February 5, 1974; see R. Churchill et al., New Directions in the Law of the Sea, Vol. 4 (Oceana Publications, 1975) 117-133.
} 
to the strategic importance and the potential oil resources of the Diaoyu Islands, both parties have been reluctant to compromise.

Joint development of marine resources around the Nansha Islands in the South China Sea has also been considered by China. In August 1990 during a visit to Singapore, the Chinese premier announced that "China is ready for joint efforts with Southeast Asian countries to develop the [Nansha] islands, while putting aside for the time being the question of sovereignty". ${ }^{61}$ At the 1992 ASEAN Foreign Ministers' Conference, China's foreign minister said: "China is in favour of shelving the matter of territorial sovereignty and concentrating on cooperative activities in the area . . ." ${ }^{62}$ At the ASEAN Regional Forum held in July 1995, he re-affirmed China's policy of putting aside disputes and negotiating joint development before the disputes are settled. He observed that China's ratification of the UN Convention on the Law of the Sea in May 1996 and the notification of territorial sea baselines had created better conditions for territorial negotiations and consultations with the neighbouring States concerned. ${ }^{63}$ China's endeavour to settle disputes in the South China Sea by reference to accepted norms of international law, and through practical arrangements like joint development, has been welcomed in the region. However, as indicated above, the disputes relating to the Nansha Islands raise a range of complex issues among six parties, and it seems unlikely that agreement among them can be reached quickly.

\footnotetext{
${ }^{61}$ See as quoted in T.L. MCDoRMAN, supra n. 36, p. 274.

${ }^{62}$ See as quoted in M. BocIURKIw, 'China Suspends Claim on Spratlys', South China Morning Post, July 22, 1992, 11.

${ }^{63}$ See People's Daily, July 24, 1996, 6.
} 